\title{
MEMBERDAYAKAN MASYARAKAT DALAM MENINGKATKAN KUALITAS HIDUP MELALUI BIDANG PENDIDIKAN, LINGKUNGAN, EKONOMI DAN KESEHATAN
}

\author{
Rusdi Kasman ${ }^{1}$, Saefullah Hidayat, Ahmad Sodikin ${ }^{2}$ \\ rusdikasman@uika-bogor.ac.id \\ Dosen Fakultas Keguruan dan Ilmu Pendidikan ${ }^{1}$, Mahasiswa KKN Kelompok 58 Tahun \\ $2017^{2}$
}

\begin{abstract}
ABSTRAK
Mahasiswa mempunyai peran strategis sebagai agent of change. Kuliah Kerja Nyata (KKN) adalah salah satu wujud pengabdian mahasiswa perguruan tinggi kepada masyarakat lewat pemberian bantuan pemberdayaan, pelatihan, penyuluhan, pembimbingan, pendampingan dan untuk menyadarkan potensi yang dimiliki, serta membantu meningkatkan kualitas hidup dan pembangunan. Mahasiswa akan mendapatkan kemampuan generatif berupa life skills (keterampilan hidup). Observasi dilakukan dengan metode silaturahmi, wawancara, dokumentasi, dan melihat ke lapangan secara langsung. Berdasarkan hasil observasi maka ditentukan program kerja KKN kelompok 58 yang akan dilaksanakan meliputi program bidang pendidikan, bidang ekonomi, bidang kesehatan, dan bidang lingkungan yang dapat dilaksanankan di Desa Cibitung Tengah Rw 05 dengan melihat potensi masyarakat dan keadaan lingkungan yang mendukung. Program bidang pendidikan yaitu membantu mengajar di TKQ dan TPQ Sabilul huda, MI At-taqwa, mengadakan bimbingan belajar Calistung, IPA, Matematika, Bahasa Inggris dan Komputer. Program bidang kesehatan yaitu senam sehat dan Penyuluhan PHBS. Program bidang ekonomi yaitu demo jajanan sehat dan pemanfaatan kulit singkong menjadi produk kripik kulit singkong. Dan program bidang lingkungan yaitu penanaman apotik hidup, reboisasi dan Plangsiasi pembatas wilayah per Rt di Rw 05. Dengan demikin, setelah kegiatan KKN berakhir diharapkan para warga Desa Cibitung Tengah Rw 05 dapat terus mengembangkan segala potensi yang ada.
\end{abstract}

Kata Kunci : Ekonomi, Kesehatan, Lingkungan, Meningkatkan Kualitas Hidup, Pendidikan.

\section{PENDAHULUAN}

Tenjolaya adalah sebuah kecamatan yang terdapat di Kabupaten Bogor, Provinsi Jawa Barat, Indonesia. Tenjolaya merupakan kecamatan yang dimekarkan dari kecamatan ciampea pada tahun 2004. Kecamatan Tenjolaya memiliki 6 kelurahan yaitu Cibitung Tengah, Cinangneng, Gunung Malang, Situ Daun,
Tapos I, dan Tapos II. Dari beberapa desa yang terdapat di Kecamatan Tenjolaya banyak warga yang bekerja sebagai petani sayur-mayur dan pedagang.

Desa Cibitung Tengah merupakan salah satu desa dari Kecamatan Tenjolaya, dengan Rw yang berjumlah $5 \mathrm{Rw}$, masyarakat di Desa Cibitung Tengah ratarata bekerja sebagai petani, sedangkan sebagiannya memilih mencari pekerjaan di 
luar desa merantau ke kota. Banyak potensi alam yang bisa dimanfaatkan, berupa hasil pertanian dan dari sumber alam lainnya.

\section{Keadaan Geografis}

Secara umum kadaan geografis Desa Cibitung Tengah adalah merupakan daerah dataran rendah dengan ketinggian antara 1350 M diatas Permukaan laut. Dengan suhu rata-rata $27,5 \mathrm{C}$ dengan kemiringan antara 25-35. Di sebelah timur dibtasi oleh sungai cinangneng, yang menjadi perbatasan dengan Desa Situdaun, disebelah Barat oleh sungai Ciampea yang sekaligus menjadi batas antara desa Cibitung Tengah dengan Desa Ciampea Udik Kecamatan Ciampea. dan berikut pemakaian lahan di desa Cibitung Tengah:

\begin{tabular}{|c|l|c|}
\hline No & Keterangan & Luas \\
\hline 1 & Sawah & $25,3 \mathrm{H}$ \\
\hline 2 & Perikanan & $0,5 \mathrm{H}$ \\
\hline 3 & Hutan Rakyat & $68,5 \mathrm{H}$ \\
\hline 4 & Pekarangan Pemukiman & $73,6 \mathrm{H}$ \\
\hline 5 & Lain-Lain & $142,7 \mathrm{H}$ \\
\hline
\end{tabular}

Sebagaimana wilayah Indonesia lainnya, Desa Cibitung Tengah pengaruhi oleh 2 (dua)musim, yaitu musim kemarau dan musim penghujan, Desa Cibitung Tengah beriklim Tropis dengan curah hujan rata-rata setahun tercatat $32 \mathrm{~mm}$ dari 0,08 dari hujan.

\section{Jumlah Penduduk}

\begin{tabular}{|c|l|c|}
\hline No & Jenis Kelamin & Jumlah \\
\hline 1 & Laki-Laki & 4.971 \\
\hline 2 & Perempuan & 5.673 \\
\hline 3 & Kepala Keluarga & 3.109 \\
\hline
\end{tabular}

Situasi ketentraman dan ketertiban diwilayah Desa Cibitung Tengah cukup kondusif, tidak adanya kejadian-kejadian yang menonjol yang mengakibatkan terhambatnya penyelenggaraan Pemerintahan. Oleh sebab itu masyarakat Desa Cibitung Tengah cukup memahami menjaga lingkungannya ditambah lagi dengan adanya LINMAS Desa yang selalu koperatif menjaga lingkungan yang ada di masing-masing wilayahnya.

Pemahaman Ideology masyarakat berkembang dengan pesat, semula Ideology haya berpusat pada Ideology politik yang berkaitan dengan negara yaitu Pancasila, namun seiring dengan globalisasi, pemahaman Ideology berkembang pada suatu pengeRtian bahwa Ideology dengan Dasar Negara adalah berbeda, Pancasila telah diletakan sebagai Dasar Negara dan bukan merupakan asas tunggal dalam kehidupan suatu organisasi.

Pancasila diletakan sejajar dengan asas lainnya yang berjalan beriringan dan dijadikan sebagai pedoman dalam menjalankan roda organisasi, karena dengan berjalannya pemahaman, diserahkan kepada pandangan masyarakat masing-masing, hal tersebut sedikit banyak berpengaruh pula terhadap kehidupan sosial politik masyarakat, pembaharuan pembinaan satuan bangsa berjalan sebagaimana mestinya, tidak ada kerawanan sosial yang mengarah pada isu syara, situasi dan kondisi sosial Ppolitik diwilayah Desa Cibitung Tengah cukup kondusif, kejadian yang meonjol yang berkaitan dengan politik dapat diselesaikan dengan baik.

Dari hasil identifikasi, perekonomian masyarakat di Rw 05 belum berkembang karena kepedulian masyarakat terhadap potensi Sumber Daya Alam yang ada di daerah tersebut masih kurang. Pola pikir masyarakat yang sulit dikembangkan karena masih mengandalkan bank keliling (Rentenir) sebagai opsi pertama untuk 
mengembangkan pembiayaan masyarakat terhadap kebutuhan sehari-harinya. Padahal di lingkungan masyarakat sendiri sudah terdapat Baitul Maal Wa Tanwin (BMT) sebagai koperasi syariah yang dapat membantu perekonomian masyarakat. rata-rata masyarakat di Rw 05 bekerja sebagai buruh proyek, petani, wiraswasta, karyawan dan merantau ke luar daerah. Sedangkan untuk para ibu rumah tangga di lingkungan masyarakat Rw 05 terkadang sebagai pekerja borongan dan kurangnya pemanfaatan sumber daya alam yang dihasilkan dari pertanian berupa singkong, jagung, terong, ubi, dan buah jambu biji. Kendala berikutnya yaitu banyak pula masyarakat yang menjadi buruh proyek disebabkan kurangnya pengetahuan mengenai potensi alam yang dapat dimanfaatkan dan bisa menghasilkan nilai ekonomi yang tinggi. Faktor lapangan pekerjaan yang sempit pun menjadi dorongan bagi sebagian masyarakat untuk memilih merantau ke luar daerah mencari penghasilan.

Menurut hasil data survey yang didapatkan dari Rw 05 pendidikan di lingkungan Rw 05 sudah mulai berkembang mulai dari pendidikan formal sampai pendidikan religius. Namun masih banyak pula masyarakat yang tidak melanjutkan sekolah ke jenjang yang lebih tinggi seperti melanjutkan ke tingkat SMA dan Perguruan Tinggi karena faktor perekonomian yang rendah, sehingga banyak anak-anak warga setempat yang lulus Sekolah Dasar atau Sekolah Menengah PeRtama merantau ke daerah lain atau ke luar kota tidak melanjutkan pendidikannya. 


\section{METODE PENGABDIAN}

Tahapan pelaksanaan pada kegiatan ini, dapat dilihat pada bagan dibawah ini:

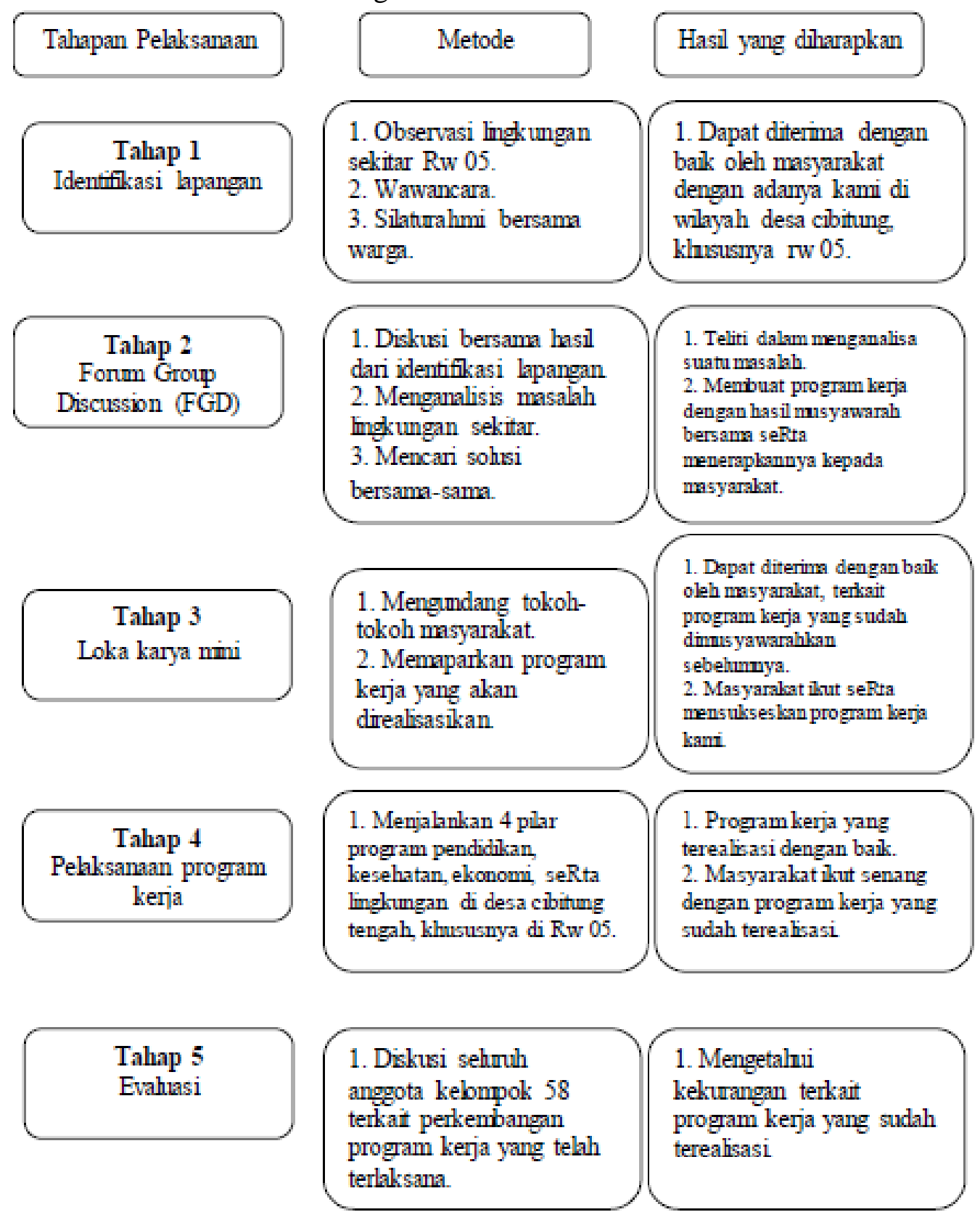


Jadwal Kegiatan

\begin{tabular}{|c|c|c|c|c|c|c|}
\hline \multirow[t]{2}{*}{ No } & \multirow{2}{*}{\multicolumn{2}{|c|}{ Kegiatan }} & \multicolumn{4}{|c|}{$\begin{array}{c}\begin{array}{c}\text { Agustus dan } \\
\text { September } 2017\end{array} \\
\text { Minggu }\end{array}$} \\
\hline & & & \begin{tabular}{l|l}
1 & 2 \\
\end{tabular} & 3 & 4 & 1 \\
\hline 1 & \multicolumn{2}{|r|}{ Penyusunan Rencana kegiatan } & & & & \\
\hline 2 & \multicolumn{2}{|r|}{ Identifikasi dan Sosialisasi Kepada Masyarakat } & & & & \\
\hline 3 & \multicolumn{2}{|r|}{ Loka Karya Mini Bersama Tokoh Masyarakat } & & & & \\
\hline \multirow[t]{8}{*}{4} & \multicolumn{2}{|r|}{ PROGRAM BIDANG PENDIDIKAN } & & & & \\
\hline & $\mathrm{a}$ & Mengajar di TKQ Sabilul Huda Rt 17 A & & & & \\
\hline & $\mathrm{b}$ & Mengajar di TPQ Sabilul Huda Rt 17 A & & & & \\
\hline & $\mathrm{c}$ & Mengajar di MI At-taqwa Rt 16 A & & & & \\
\hline & $\mathrm{d}$ & $\begin{array}{l}\text { Mengajar BIMBEL CALISTUNG Kelas TK, 1, 2, dan } 3 \text { SD di } \\
\text { posko KKN Rt } 20\end{array}$ & & & & \\
\hline & e & $\begin{array}{l}\text { Mengajar BIMBEL Matematika, IPA, Bahasa Inggris Kelas 4, 5, } \\
\text { dan } 6 \text { SD di Posko KKN Rt } 20\end{array}$ & & & & \\
\hline & f & $\begin{array}{l}\text { Mengajar BIMBEL Bahasa Inggris, Komputer, Matematika } \\
\text { Kelas SMP dan SMA di Posko KKN Rt } 20\end{array}$ & & & & \\
\hline & $\mathrm{g}$ & Seminar Parenting di TKQ Sabilul Huda Rt 17 A & & & & \\
\hline \multirow[t]{3}{*}{5} & \multicolumn{2}{|r|}{ PROGRAM BIDANG KESEHATAN } & & & & \\
\hline & $\mathrm{a}$ & Senam Sehat Rw 05 & & & & \\
\hline & $\mathrm{b}$ & $\begin{array}{l}\text { Penyuluhan PHBS (Perilaku Hidup Bersih dan Sehat) di TKQ } \\
\text { Sabilul Huda }\end{array}$ & & & & \\
\hline \multirow[t]{3}{*}{6} & \multicolumn{2}{|r|}{ PROGRAM BIDANG EKONOMI } & & & & \\
\hline & $\mathrm{a}$ & Demo Jajanan Sehat di Posko KKN Rt 20 & & & & \\
\hline & $\mathrm{b}$ & $\begin{array}{l}\text { Pengenalan dan praktek pemanfaatan kulit singkong menjadi } \\
\text { olahan kripik kulit singkong di posko KKN Rt } 20\end{array}$ & & & & \\
\hline \multirow[t]{4}{*}{7} & \multicolumn{2}{|r|}{ PROGRAM BIDANG LINGKUNGAN } & & & & \\
\hline & $\mathrm{a}$ & Penanaman Apotik Hidup di Rw 05 & & & & \\
\hline & $\mathrm{b}$ & Reboisasi 100 Pohon Sengon di Rw 05 & & & & \\
\hline & $\mathrm{c}$ & Membuat Plang batas wilayah per Rt di Rw 05 & & & & \\
\hline \multirow[t]{8}{*}{8} & \multicolumn{2}{|r|}{ KEGIATAN LAIN-LAIN } & & & & \\
\hline & $\mathrm{a}$ & $\begin{array}{l}\text { Keterlibatan dalam kegiatan PHBS yang diadakan oleh } \\
\text { PAMSIMAS di Rw } 05\end{array}$ & & & & \\
\hline & $\mathrm{b}$ & Pengajian Satu Desa Rw 05 & & & & \\
\hline & $\mathrm{c}$ & Gotong Royong memperbaiki akses jalanRw 05 bersama warga & & & & \\
\hline & $\mathrm{d}$ & Pembuatan Gapura 17 Agustus Rw 05 & & & & \\
\hline & e & Partisipasi Upacara HUT RI Sekecamatan Tenjolaya & & & & \\
\hline & $\mathrm{f}$ & Partisipasi acara kegiatan 17 Agustus di Rw 05 & & & & \\
\hline & $\mathrm{g}$ & Penyuluhan Sampah & & & & \\
\hline
\end{tabular}

Metode Pendekatan

Pendekatan yang digunakan dalam kegiatan ini adalah:

1. Pendekatan organisasi, yaitu pendekatan pada pemuda pemudi, jajaran masyarakat (Rw/Rt) serta pendekatan dengan ibu-ibu majlis pada TKQ Sabilul Huda.

2. Pendekatan berdasarkan karakter masyarakat, yaitu dengan mendekatkan masyarakat pada hal-hal positif yang dapat membantu mereka dalam ruang 
lingkup pendidikan, kesehatan, ekonomi, seRta lingkungan. Hal ini dilakukan untuk memberi pengalaman yang nyata kepada masyarakat tentang sesuatu yang positif untuk kebaikan bersama.

3. Pendekatan kekerabatan, aRtinya pengarahan yang sudah dilakukan senantiasa dikaitkan hanya untuk membangun kekerabatan dengan masyarakat cibitung tengah, khususnya pada Rw 05.

\section{Langkah Evaluasi}

Evaluasi yang akan dilakukan terdiri dari:

1. Evaluasi proses, yakni evaluasi yang terkait dengan perencanaan seRta pelaksanaan kegiatan. Evaluasi proses akan dilakukan setiap pekan oleh seluruh anggota kelompok 58.

2. Evaluasi hasil, yakni evaluasi yang akan dilaksanakan setelah kegiatan berlangsung. Evaluasi hasil ditujukan untuk menguji pemahaman warga, sudah sejauh mana mereka mengeRti serta paham dengan pembinaan dan seminar yang sudah pernah disosialisasikan oleh mahasiswa KKN kelompok 58 Universitas Ibn Khaldun Bogor.

\section{Partisipasi Masyarakat dalam Pelaksanaan Program}

Partisipasi masyarakat yang dilakukan dalam kegiatan ini adalah sebagai berikut:

1. Mempersiapkan masyarakat yang bersedia untuk mengikuti pembinaan seRta seminar yang akan dilakukan.

2. Membantu mensosialisasikan kepada masyarakat yang mengikuti pembinaan baik tentang pendidikan maupun kesehatan.
3. Membantu mengarahkan tempat untuk pengadaan kegiatan yang akan dilakukan.

4. Mempersiapkan tempat untuk pembuatan semi gapura.

5. Ikut berkontribusi dalam pembangunan semi gapura.

6. Mempersiapkan lahan untuk pelaksanaan reboisasi 100 pohon kayu sengon.

7. Ikut seRta dalam pelaksanaan senam sehat yang diadakan setiap satu minggu sekali.

8. Ikut serta dalam pelaksanaan penanggulangan sampah, seRta demo jajanan sehat.

\section{REALISASI PROGRAM}

\section{Loka Karya Mini}

Kegiatan sosialisasi program KKN merupakan suatu program yang tujuannya memberikan gambaran kepada para tokoh masyarakat maupun warga masyarakat $\mathrm{Rw}$ 05 Desa Cibitung Tengah, Agar masyarakat di RW 05 dapat mengetahui, memahami program kerja yang telah ditetapkan oleh mahasiswa KKN, dan agar masyarak dapat bekerja sama dalam mendukung dan berpartisipasi dalam pelaksanaan program kerja mahasiswa KKN. Pelaksanaan sosialisasi dilaksankan tanggal 13 Agustus 2017 bertempat di Posko KKN Kelompok 58 Rt 20. Sasaran kegiatan Loka Karya Mini ini adalah masyarakat Rw 05. Dalam berlangsungnya kegiatan forum sosialisasi, beberapa perwakilan masyarakat memberikan masukan-masukan yang membangun untuk menyempurnakan program kerja yang akan dilaksanakan, serta terdapat tambahan program untuk tim KKN kelompok 58 UIKA 2017 yang melibatkan warga Rw 05 Desa Cibitung Tengah. Faktor pendukung 
dari terlaksananya program sosialisasi yaitu tersedianya kelengkapan sarana dan prasarana yang mendukung berjalannya kegiatan tersebut, tidak ada faktor penghambat kegiatan loka karya mini ini. Kegiatan berjalan lancar dan aman sesuai rancangan.

\section{Program Bidang Pendidikan}

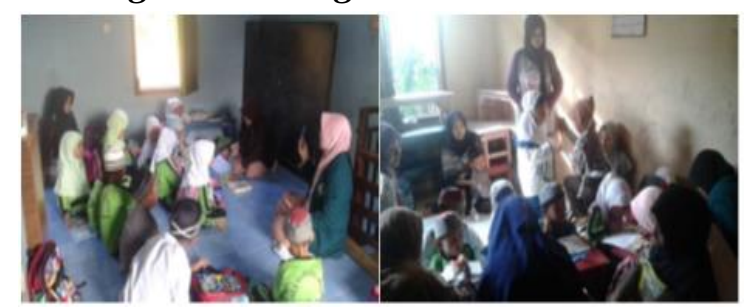

a. Kegiatan Membantu Mengajar di TKQ Sabilul huda

b. Kegiatan Membantu Mengajar di MI At-taqwa

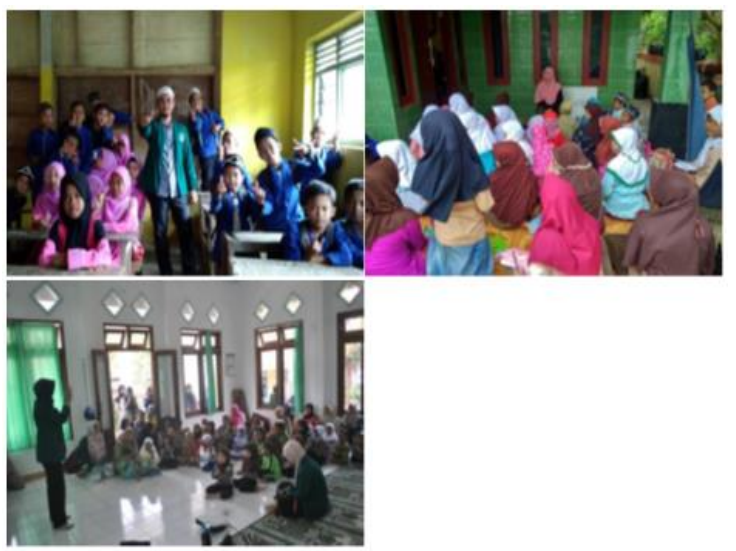

c. Kegiatan Mengadakan Bimbingan Belajar

CALISTUNG

(Baca,Tulis,Hitung).

d. Kegiatan Mengadakan Bimbingan Belajar Matematika, IPA, dan Bahasa Inggris (SMP).

e. Kegiatan Mengadakan Bimbingan Belajar Matematika, Bahasa Inggris, dan Komputer (SMA).

f. Kegiatan Seminar Parenting

\section{Program Bidang Kesehatan}

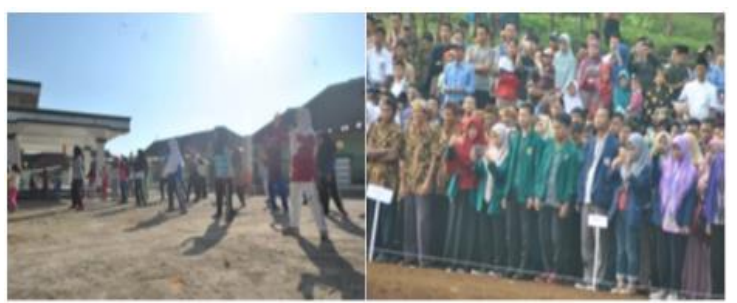

a. Kegiatan Senam Sehat

b. Kegiatan Penyuluhan PHBS (Perilaku Hidup Bersih dan Sehat)

\section{Program Bidang Ekonomi}

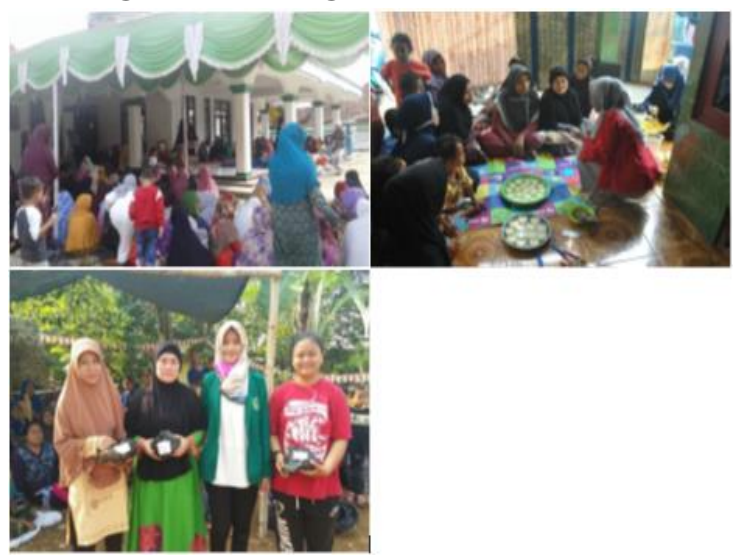

a. Kegiatan Demo Jajanan Sehat

b. Penyuluhan pemanfaatan kulit singkong menjadi produk kripik kulit singkong

\section{Program Bidang Lingkungan}

a. Penanaman Apotik Hidup

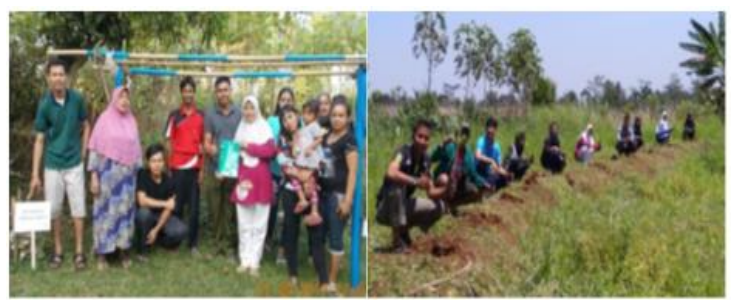

b. Reboisasi Penanaman 100 Pohon Sengon

c. Pembuatan Plang Pembatas Wilayah RT di RW 05 


\section{Kegiatan Lain-Lain}

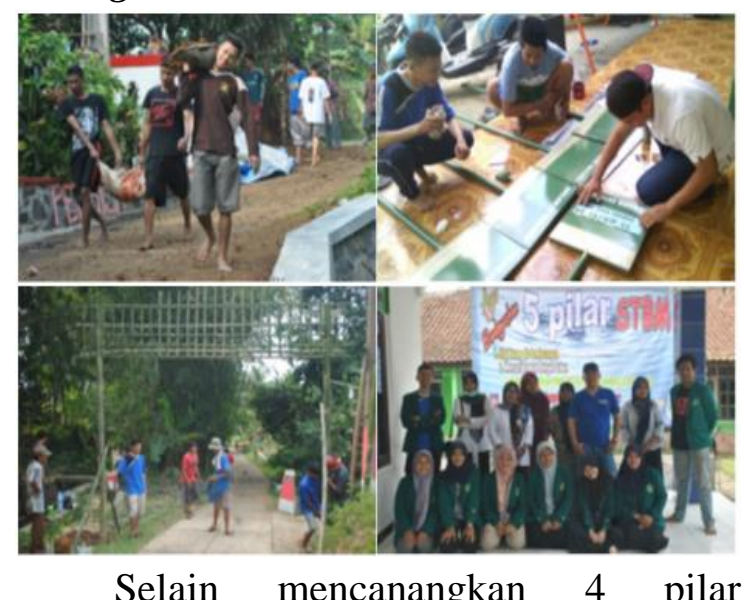

program, kami juga melaksanakan kegiatan lain seperti, Bekerjasama Sosialaisasi PHBS Bersama PAMSIMAS, Gotong Royong Memperbaiki Akses Menuju RW 05, Pembuatan Gapura 17 Kemerdekaan, Partisipasi dalam Upacara Peringatan Hut RI Sekecamatan Tenjolaya, Pengajian Satu Desa di RW 05, Partisipasi Acara 17 Agustus di RW 05, dan Penyuluhan Sampah. Semua kegiatan ini berjalan dengan maksimal karena adanya sosialisasi dan kerjasama yang baik antara mahasiswa dengan masyarakat ataupun dengan aparat pemerintahan Desa Cibitung Tengah. Tidak ada kendala atau permasalahan yang dapat menghambat kegiatan sehingga keterlibatan kami dalam melaksanakan tugas sangat nyaman dan mudah.

\section{KESIMPULAN}

Setelah dilakukan observasi lapangan dan dilanjutkan dengan pembuatan rencana program kerja dengan pelaksanaannya selama satu bulan, mulai tanggal 7 Agustus sampai dengan 7 September 2017, kami mahasiswa KKN Universitas Ibn Khaldun Bogor, yang bertempat di Desa Cibitung Tengah Rw 05 Kecamatan Tenjolaya Kabupaten Bogor. Kami dapat menyimpulkan bahwa selama satu bulan melaksanakan Kuliah Kerja Nyata (KKN) dan merealisasikan berbagai program seperti program bidang pendidkan, program bidang kesehatan, program bidang ekonomi, dan program bidang lingkungan berjalan dengan baik. Berdasarkan pengalaman dan kondisi lapangan yang kami peroleh melaui Kuliah Kerja Nyata (KKN) dapat kami simpulkan sebagi berikut:

1. Pada program bidang pendidikan terlaksana dengan baik dan dapat meningkatkan ilmu pengetahuan masyarakat Rw 05, terutama pada anakanak yang masih membutuhkan bantuan pengajaran ilmu teknologi seperti Bimbingan belajar komputer.

2. Program bidang kesehatan yaitu senam sehat dan penyuluhan PHBS berjalan dengan baik dan lancar antusiasme warga dan anak-anak di Rw 05 sangat tinggi serta para staf guru di TKQ Sabilul Huda yang telah mengizinkan kami untuk mensosialisasikan mengenai kesehatan.

3. Melaui program bidang ekonomi mengenai demo jajanan sehat dan pemanfaatan kulit singkong masyarakat Rw 05 sangat merasakan manfaatnya dalam pengembngan wawasan serta peningkatan perekonomian warga baik secara pribadi maupun dalam satu wilayah Rw tersebut.

4. Pada program-program bidang lingkungan yang kami laksanakan seperti membuat pembatas wilayah per Rt, reboisasi, dan penanaman apotik hidup, sangat bermanfaat dan dirasakan sangat membantu oleh warga setempat.

\section{Dampak bagi masyarakat}

Program KKN Tematik Terintegrasi bertujuan untuk mengembangkan potensipotensi yang ada di lingkungan Desa 
Cibitung Tengah khususnya di Rw 05 yang menjadi fokus kerja kelompok 58, yang berdampak pada pembangunan perekonomian, pendidikan, kesehatan, dan lingkungan di wilayah Rw 05. Dampak yang muncul dan dirasakan oleh masyarakat yaitu semakin berkembangnya perekonomian warga, semakin majunya pendidikan warga, semakin terbukanya wawasan masyarakat akan pentingnya kesehatan, semakin terciptanya lingkungan yang kondusif, bersih dan sehat di wilayah Rw 05. Dari aspek pendidikan, masyarakat sangat antusias dan merasa terbantu karena adanya program bantuan mengajar untuk anak-anak warga Rw 05, begitupun dari pihak lembaga pendidikan. Keberadaan program pendidikan yang kami realisasikan dapat memberikan wawasan mengenai teknologi maapun pengetahuan baru yang bermanfaat bagi masyarakat. Dari aspek lingkungan, program yang sudah dijalankan diharapkan dapat berdampak pada bertambahnya kesadaran masyarakat akan pentingnya menanam pohon, lalu kami juga menyosialisasikan program one man one tree yang diharapkan dapat merubah mindset warga yang tadinya selalu menebang pohon, berubah menjadi penanam pohon dengan satu orang merawat minimal satu pohon. Program penanggulangan sampah juga diharapkan dapat merubah pola pikir warga yang tadinya membuang sampah ke sungai, beralih menjadi ke tanah dengan sampah organik yang dijadikan pupuk, sedangkan untuk sampah anorganik dapat diubah menjadi kerajinan tangan yang bermanfaat, kami pula mengampanyekan kebiasaan membawa tas belanja dari bahan yang bisa digunakan ulang sehingga diharapkan dapat mengurangi sampah kantong plastik yang berlebih.

\section{SARAN}

a. Program-program yang telah dilaksanakan oleh mahasiswa sebaiknya ada pengembangan atau tindak lanjut untuk peningkatan selanjutnya.

b. Hubungan yang sudah terjalin antara pihak Universitas dengan pihak masyarakat hendaknya dapat lebih ditingkatkan dan dapat memberikan umpan balik satu sama lainnya.

\section{REFERENSI}

Administrasi Profil Desa Cibitung Tengah

https://id.m.wikipedia.org/wiki/Tenjolaya, _Bogor

Petunjuk Pelaksanaan KKN Tematik Terintegrasi 2017 Universitas Ibn Khaldun Bogor

survey mahasiswa KKN RW 05 Desa Tenjolaya 2017 